\title{
Supply and Regulation Services Provided by Re-greened Landscapes in the Sahel: Case of Two Villages' Clusters Dan Saga and Tabofatt in Niger Republic
}

\author{
S. Saidou, D. G. Iro, and K. J.-M. Ambouta
}

\section{ABSTRACT}

The objective of this study is to assess the importance of the supply and regulation services provided by the regreened landscapes in certain anthropized areas of Sahel zone. The methodology used is based on a socioeconomic survey coupled with an inventory of woody vegetation in agroforestry parks in two villages' clusters: Dan Saga and Tabofatt. Ethnobotanical analysis tools and allometric equations are applied on the data collected. These led to three main results. First, a total of 43 and 34 species registered are used in six (6) usages, such as food, forage, technological, energetic, and medicinal uses respectively both in Dan Saga and Tabofatt cluster. Second, the two landscapes contain a remarkable specific flora diversity which contributes not only to soil fertility but also to sequester 6.04 \pm 0.236 and $4.59 \pm 0.568$ tCO2.ha-1 respectively at Dan Saga and Tabofatt. And thirdly in the landscapes of two clusters the amount of woody species inventoried, meets the amount of social use requirements. These results show that scaling up of regreening program should focus on promoting useful species through updating the current forest legislation.

Keywords: Ecosystem services, Landscape, Regreening, Agroforestry species.

\section{INTRODUCTION}

The concept of Ecosystem Services (ES) emerged in the 1970 s at the interface of ecological and economic approaches. It acquires international importance at the summit of the Millennium Ecosystem Assessment [26], where it is perceived as all the benefits that people derive from the ecosystem. This definition emphasizes on the capacity of natural processes and components to provide goods and services to humans [12]. However, this vision is based on a plea in favor of the conservation of nature since it places human being at the heart of the natural systems from which he benefits through an environmentally sound and sustainable management of ecosystems. However, knowledge about the interactions between ecosystem services and human well-being is insufficiently known [7]. It is from this perspective that [8] proposed a monetary valuation system for ecosystem services based on landscapes, ecosystems and biomes.

But for the particular case of the Sahel, despite the regreening observed in certain areas by many authors such as [31], [4], [20], [28], [23], the evaluation of the services provided by this positive change is still to be assessed. Most of the studies that are interested in this topic were very often limited to a characterization of the vegetation cover or a rather fragmentary analysis of the socioeconomic impacts of the natural resources. Therefore, it will be interesting to
Published Online: January 21, 2021

ISSN: $2684-1827$

DOI: $10.24018 /$ ejfood.2021.3.1.216

\section{S. Saidou*}

Ecole Doctorale de Sciences de la Vie et de la Terre, Université Abdou Moumouni de Niamey, Niger.

(e-mail: saidousalifou229@gmail.com).

D. G. Iro

Faculté d'Agronomie département du Génie Rural et Eaux et Forêts, Université Abdou Moumouni de Niamey, Niger.

(e-mail: danguimbo@yahoo.fr).

K. J.-M. Ambouta

Département Sciences du Sol, Faculté d'Agronomie, Université Abdou

Moumouni de Niamey Niger.

(e-mail: ambouta.karimou@ ${ }^{@}$ ahoo.fr).

*Corresponding Author address some relevant questions in order to get a deep understanding of the recent regreening process that is occurring in some anthropized areas of Sahel zones. How important are these services in terms of supply and regulation that can justify the large-scale adoption of best Sustainable Land Management (SLM) practices which explain the regreening process? Is there a relationship between the availability of agroforestry resources and the various usages to which they are subject? Faced with these questions, the main objectives of this study are first to assess the importance of supply and regulatory ecosystem services provided by the re-greened landscape in the Sahel and secondarily to identify the adequacy that exists between the ecological supply of species and the socioeconomic needs of the local inhabitants.

\section{PROCEDURE FOR PAPER SUBMISSION}

\section{A. Study Sites}

Two villages' clusters were chosen to conduct this study. These are the Dan Saga cluster located in the department of Aguié in south-central Niger (Fig. 1) and the Tabofatt cluster located in the Keita department, Ader Doutchi Maggia (Fig. 2). The two clusters are both distinguished by their high population density of over 100 inhabitants per $\mathrm{km}^{2}$. Studies using remote sensing and Geographic and Informative System (GIS) technics have proven that the two 
zone are undergone a recent changing of woody vegetation cover. The driver factor of this change depends of the local soil and climate conditions. At Dan Saga cluster with sandy plateau, people use Assisted Tree Natural Regeneration (ATNR) that has favored a return of woody cover [30], [27], [18]. In the case of the Tabofatt cluster with stony contrasted plateau, people use planting trees of the genus acacia coupled with water and soil erosion control practices that result in to revegetate the landscape [30], [1].

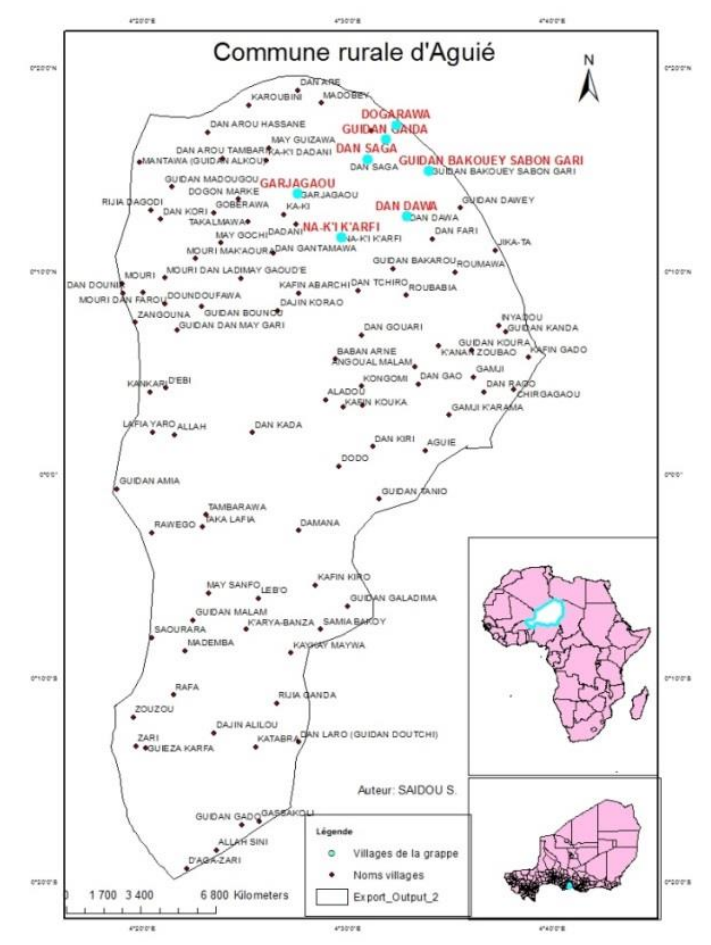

Fig. 1. Location map of study areas Dan Saga.

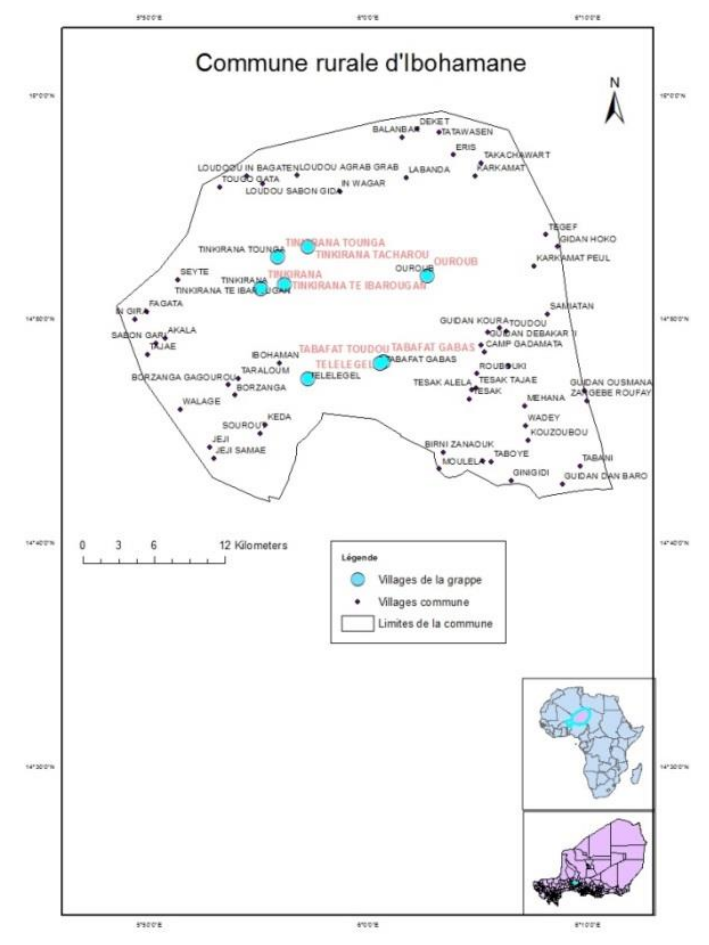

Fig. 2. Location map of study areas Tabofatt.

\section{B. Collection of Data}

Two types of data were used to identify the importance of ecosystem services from regreened landscapes in the two clusters. The first data come from an ethnobotanical survey. They aim to collect the people perception on socioeconomic importance of woody species located in agroforestry parks. For this purpose, questionnaires for unstructured focus group interviews and individual questionnaires were designed using Sphynx V5++ software. These questionnaires focus on aspects relating on the usage of woody species. The categories of usages for the range of supply services selected are: human food and fodder, timber and energy supply, and medicinal uses. These surveys were conducted during the month of August 2018 in the two clusters. They involved six groups and 100 people at the Dan Saga cluster and 5 groups and 100 people at the Tabofatt cluster. The choice of individual interviewed was made using simple random sampling with a $10 \%$ margin of error. Group surveys aim at consolidating and validating the information collected in individual surveys.

The second set of data comes from an inventory of woody plants in agroforestry parks. It aims to determine the ecological characteristics of the woody vegetation that should allow understanding of the importance of certain regulatory services. The inventory was made on radiary transects in plots of $50 \mathrm{~m} \times 50 \mathrm{~m}$ arranged along the transects with an equidistance of $200 \mathrm{~m}$. It consisted of counting and dendrometric measurements of all woody individuals located inside the plots. A total of 85 and 45 inventory plots were inventoried respectively at the Dan Saga cluster and the Tabofatt cluster. The denomination of the species was carried out with reference to [2] and [33]. The ecological parameters from these inventories were used to establish the importance of regulatory services, in particular: the improving role of woody species on soil fertility, the potential for carbon sequestration and the enhancement of biodiversity.

\section{Data Analysis}

Assessment of supply services

Perception survey data on the uses of woody species in agroforestry parks served as the basis for the analysis to show the importance of provisioning services. Thus, the Consensual Informative Factor (CIF) index was calculated for food, feed, technological usage, energy and medicinal uses. This index is calculated using (1) [15].

$$
C I F=\frac{N u r-N t}{N u r-1}
$$

In (1), Nur is the number of times a use category was mentioned and $N t$ is the number of species mentioned for that category. It has the advantage of homogenizing botanical information.

The existence of homogeneous use-species groupings was made through Multiple Correspondence Analysis using the XLSAT software. The projection of the analysis results on two factorial plans provides a best visualization of the relationship species-usage.

\section{Assessment of Regulatory Services}

Our study has focused on three specific regulatory services such as carbon sequestration potential, tree impact on soil improving and biodiversity. For that purpose, (2) and (3) allometric regressions are performed in order to estimate 
the above-ground biomass and the below-ground biomass, which allowed carbon woody vegetation compartment stock sequestered assessment.

The above-ground biomass $(\mathrm{AB})$ is derived from the values of the diameter at the base of the trunk woody individual tree woody (D) and is obtained by the formula of (2) [24].

$$
A B(k g)=1,929 * D+0,116 * D^{2}+0,013 * D^{3}
$$

Below ground biomass (BB) is related to above ground biomass by (3) proposed by [6].

$$
B B=e^{(-1,0587+0,8836 * \ln A B)}
$$

The factor of 0.47 was applied to the total biomass to derive the dry biomass [17]. The calculation of the sequestered carbon stock is obtained by multiplying the dry biomass by a biomass expansion and conversion factor equivalent to 0.5 [22]. The conversion of the amount of carbon to the of $\mathrm{CO}_{2}$ amount equivalent was done by multiplying the carbon by affecting the factor of 3.67 which is the ratio of molecular masses $\mathrm{M}\left(\mathrm{CO}_{2}\right) / \mathrm{M}(\mathrm{C})$. In this analysis, the level of uncertainty on the results was assessed by determining the percentage error based on the protocol proposed by [25].

The quantitative estimate of soil fertility potential is assessed through the importance of indicator species of soil fertility calculated on the basis of the results of the inventory. The ecological importance of a species is measured by the Significance Value Index (4).

$$
\begin{aligned}
& \text { SVI }=\text { Relative dominance }+ \text { Relative density }+ \\
& \text { Relative frequency }
\end{aligned}
$$

The enhancement of phytodiversity in the landscape is demonstrated using the Shannon-Weaver diversity index (5), the Pielou equity index (6) and the total number of species in the landscape.

$$
\begin{aligned}
& H^{\prime}=-\sum_{i=1}^{n} P_{i} * \log _{2} P_{i} . \\
& E q=\frac{H}{\log _{2} S}
\end{aligned}
$$

Here, $P i$ denotes the absolute frequency of species $i$ and $n$ is the total number of individuals. $\mathrm{S}$ is the total number of species.

If this $\mathrm{H}^{\prime}$ is low, the environment is considered to be poor in species. On the other hand, if this index is high, the environment then conceals a significant specific diversity [34]. The Eq index provides information on the regularity of the distribution of species in an environment.

Demonstration of the links between the socioeconomic importance of agroforestry resources and the current state of the population
A correlative analysis was applied on the values of the Significance Value Index (SVI) and the Cultural Importance Index (CI). This analysis aims to highlight the link between ecological supply and socioeconomic demand expressed by the various uses of woody species. The values of the CI index were calculated using (7) proposed by [32].

$$
C I=\sum_{u=u_{1}}^{u_{N C}} \sum_{i=1}^{i_{n}} \frac{U R_{u i}}{N}
$$

In (7), $u$ designates a category of use, $N C$ the total number of categories of use, $\mathrm{N}$ is the total number of informants and $U R$ represents the number of respondents mentioning a particular category use of the species $i$.

\section{RESULTS}

\section{A. Procurement Services}

Within the meaning of the nomenclature proposed by the Millennium Summit on Ecosystem Services in 2015, supply services relate to the contribution of the restored landscape to food and fodder security, traditional pharmacopoeia and uses for technological and energetic purposes. A total of 43 and 34 species are used for various purposes respectively in Dan Saga and the Tabofatt cluster. The importance of a use category is highlighted through the number of species assigned to this use and the value of the corresponding integrating consensus factor (Table 1). All the five (5) utilizations recorded a high CIF value close to 1 . However, the medicinal usage gets the greatest number of species affected with 40 and 20 species respectively in Dan Saga and Tabofatt. Feeding and energy uses occupy a remarkable place in the two clusters. In contrast, technological usage employs a limited number of species in both clusters.

\section{B. Species-uses Grouping}

The two factorial designs F1 and F2 of the Multiple Correspondence Analysis on the species-usages matrix total a contribution of $52.10 \%$ in the explanation of the groupings obtained in the case of the Dan Saga cluster (Fig. 3). These two plans define four groups. The first GI group of species for forage and energy uses, the most characteristic species of which are: Faidherbia albida, Piliostigma reticulatum, Commiphora africana, Guiera senegalensis and Dichrostachys cinerea. The second GII group of species for food includes Ziziphus mauritiana, Tamarindus indica, Vitex doniana, Dyospiros mespiliformis and Lannea fruticosa. Group GIII of species for technological use includes some flagship species such as Combretum nigricans, Acacia senegal, Acacia seyal, Azadirachta indica and Anogeissus leiocarpus. The GIV group of species for

\begin{tabular}{|c|c|c|c|c|c|c|c|c|c|c|}
\hline \multirow[b]{2}{*}{ Usage } & \multicolumn{5}{|c|}{ Dan Saga } & \multicolumn{5}{|c|}{ Tabofatt } \\
\hline & Food & Fourrage & Techno & Energ & Medi & Food & Fourrage & Techno & Energ & Medi \\
\hline Nbre $\mathrm{Sp}$ affect & 22 & 18 & 13 & 16 & 40 & 16 & 11 & 14 & 17 & 20 \\
\hline FCI & 0,78 & 0,82 & 0,87 & 0,84 & 0,60 & 0,84 & 0,89 & 0,86 & 0,83 & 0,80 \\
\hline
\end{tabular}
medicinal use includes several species, the most important of which are Securidaca longepedonculata, Acacia nilotica, Boswelia odorata, Ximenia americana and Maerua angolensis.

TABLE 1: NUMBER OF SPECIES USED AND VALUE OF THE CONSENSUAL INFORMATIVE FACTOR (CIF) FOR FOUR CATEGORIES OF TREE WOODY SPECIES USES IN THE DAN SAGA AND TABOFATT CLUSTER

Legend: Nbre Sp affect: Number of species affected, Techno: Technological use, Energ: Energy use, Medi: Medicinal use. 


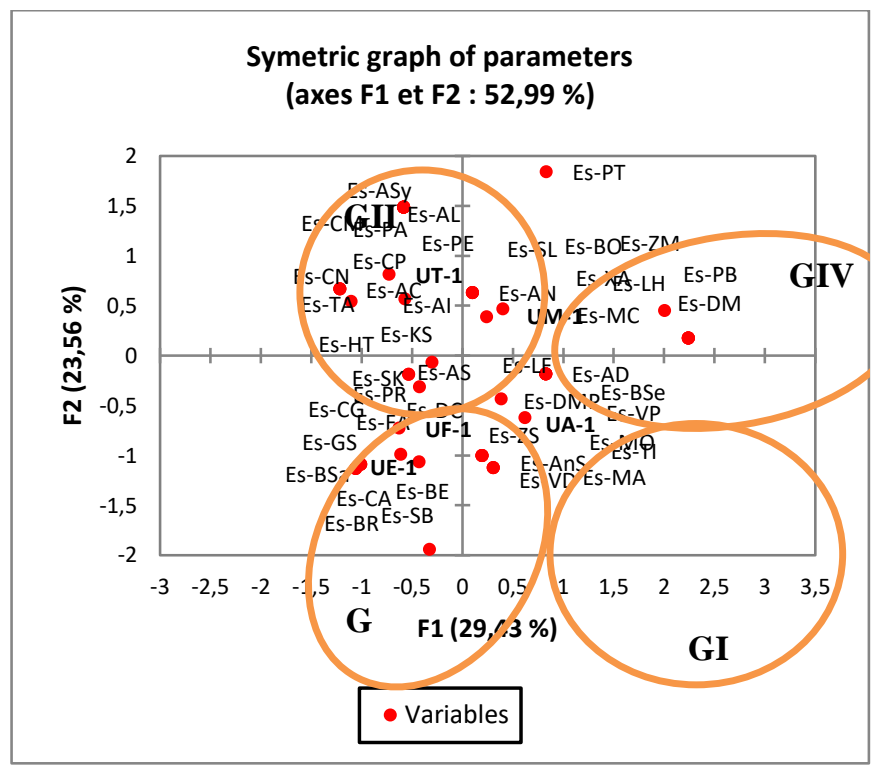

Fig. 3. Multiple Corresponding Analysis Species-Usages Results case of Dan Saga cluster.

In Tabofatt cluster the two factorial designs F1 and F2 cumulate $48.21 \%$ of contribution in the constitution of the groups (Fig. 4). On the basis of these factorial plans, three (3) groups emerge. The first group G1 of species for forage and energy use is characterized by species such as Bauhunia rufescens, Guiera senegalensis, Piliostigma reticulatum, Faidherbia albida and Combretum glutinosum. The second group G2 of species for medicinal and technological use includes Azadirachta indica, Combretum nigricans, Combretum micranthum, Prosopis juliflora and Salvadora persica. Of the third group G3 of species for specific food use, the main species such as Tamarindus indica, Adansonia digitata, Moringa oleifera and Leptadenia pyrotechnica have been cited.

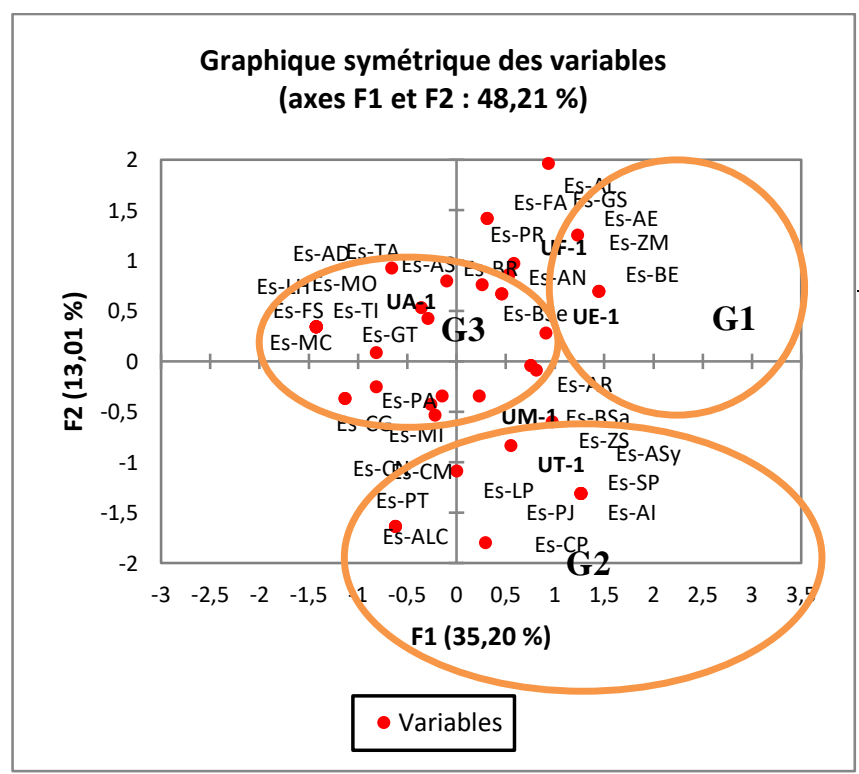

Fig. 4. Multiple Corresponding Analysis Species-Usages Results case of Tabofatt cluster.

\section{Regulatory Services}

The ecological restoration of landscapes is also supported by the provision of several regulatory services provided by the wood cover. This study identified three types of regulatory services. These are the role of improving soil fertility, carbon sequestering and strengthening of biodiversity species in the restored landscapes.

The improving role of soil fertility is generally detectable by the presence of certain tree species indicator. Based on the inventory data, several species have been identified that are indicative of soil fertility. The importance of each of these species is highlighted through their Significance Value Index.

Some indicator species for soil fertility are common to both sites (Table 2). This is the case with Faidherbia albida and Acacia senegal. Other species are on the other hand specific as for example Cassia singueana with SVI $=6.83 \%$ in Dan Saga cluster and the species Acacia seyal with SVI = $28.05 \%$ in Tabofatt cluster. In addition, we noted that the amount of tree indicator species of rich soils is much more important in the landscape of the Tabofatt cluster than are those in the landscape of the Dan Saga cluster.

TABLE 2: SigNIFICANCE VALUE INDEX OF SPECIES INDICATOR OF SOILS

\begin{tabular}{cccc}
\multicolumn{3}{c}{ FERTILITY } \\
\hline Dan Saga & \multicolumn{3}{c}{ Tabofatt } \\
\hline Tree species & SVI $(\%)$ & Tree species & SVI $(\%)$ \\
\hline Faidherbia albida & 17,35 & Faidherbia albida & 15,57 \\
Acacia senegal & 0,82 & Acacia senegal & 15,01 \\
Piliostigma & 0,10 & Acacia seyal & 28,05 \\
reticulatum & 6,83 & Acacia ehrenbergiana & 21,55 \\
$\begin{array}{c}\text { Cassia singueana } \\
\text { Dichrostachys }\end{array}$ & 0,40 & Piliostigma reticulatum & 17,49 \\
$\quad$ cinerea & & Salvadora persica & 11,65 \\
\hline Albizzia chevalieri & 4,40 & &
\end{tabular}

Legend: SVI: Significance Value Index.

Landscapes re-greened by sustainable land management actions have an attenuating effect on climate change and variability. This study emphasized on the woody component to highlight the potential for carbon sequestration in the landscape of the two clusters (Table 3 ).

TABLE 3: CARbon SEQUESTRATION PARAMETERS VALUES RESUlTS IN DAN SAGA AND TABOFATT CLUSTERS

\begin{tabular}{cccccc}
\hline \multicolumn{6}{c}{ DAN SAGA AND TABOFATT CLUSTERS } \\
\hline Cluster & $\mathrm{AB}(\mathrm{tC} / \mathrm{ha})$ & $\mathrm{BB}(\mathrm{tC} / \mathrm{ha})$ & $\mathrm{CQ}(\mathrm{tC} / \mathrm{ha})$ & $\begin{array}{c}\mathrm{CO}_{2} \mathrm{Q} \\
\left(\mathrm{tCO}_{2} / \mathrm{ha}\right)\end{array}$ & Error $(\%)$ \\
\hline Dan Saga & $5,76 \pm 0,061$ & $1,24 \pm 0,004$ & $1,65 \pm 0,065$ & $6,04 \pm 0,236$ & 2,09 \\
Tabofatt & $4,11 \pm 0,146$ & $1,21 \pm 0,009$ & $1,25 \pm 0,155$ & $4,59 \pm 0,568$ & 5,47 \\
\hline Legend: & t: tone unit, $\mathrm{AB}:$ Above & ground Biomass, BB: Below ground \\
Biomass, CQ: Carbon Quantity, $\mathrm{CO}_{2} \mathrm{Q}: \mathrm{CO}_{2}$ Quantity.
\end{tabular}

This potential is significantly greater in Dan Saga landscape $\left(6.04 \cdot 0.236\right.$ tone $\left.\mathrm{CO}_{2} / \mathrm{ha}\right)$ compared to the case of Tabofatt with $4.59 \cdot 0.568$ tone of $\mathrm{CO}_{2} /$ ha. In both cases, the uncertainty of the results is below the threshold value of $10 \%$.

The actions undertaken in the sustainable management of the land resulted in an improvement of tree woody species biodiversity in the two study sites (Table 4).

TABLE 4: VALUES OF BIODIVERSITY PARAMETERS IN THE TWO VILLAGES CLUSTERS

\begin{tabular}{ccccc}
\hline Cluster & H' (bits) & Hmax (bits) & Eq & S \\
\hline Dan Saga & 3,69 & 5,55 & 0,67 & 47 \\
Tabofatt & 2,91 & 4,52 & 0,64 & 23 \\
\hline
\end{tabular}

Legend: H': Shannon-Weaver Index, Hmax: Shannon-Weaver Index Maximum value, Eq: Pielou Index, S: Total number of tree woody species. 
Quite high values were recorded on all · diversity indexes. In addition, the diversity of woody species is significantly higher at the landscape of Dan Saga cluster compared to that of Tabofatt cluster. The results show $\mathrm{S}=43$ species and $H^{\prime}=3.69$ bits at Dan Saga versus $S=23$ species and $H^{\prime}=2.91$ bits at Tabofatt. The distribution of these species is relatively regular with a Pielou index value of 0.67 in Dan Saga and 0.64 in Tabofatt.

D. Relationship between the Importance of Agroforestry Species and Their Specific Uses

After this characterization of certain aspects relating to the supply and regulation services provided by the restored landscapes in the two clusters, it is appropriate to wonder about the ecological capacity of the landscape to respond to the various requests for these services expressed by the local inhabitants. In this sense, the cultural importance index of each species cited during the survey and the significance value index calculated on the basis of the inventory results have shown the link between the socioeconomic place of each agroforestry tree species and its relative abundance on the field.

The results of the $t$ test mean comparison show that for the two parameters the difference in means is negative (Table 5). But the difference is not significant at the alpha threshold $=0.05$. The risk of rejection of $\mathrm{H} 0$ is however higher for SVI values compared to the CI index value (28.05\% against $8.91 \%$ ). This result suggested a correlative analysis of the interdependence to clearly highlight the relationship between these two parameters.

TABLE 5: T DIFFERENCE AVERAGE TEST RESUlt APPLIED ON SIGNIFICANCE VALUE INDEX (SVI) AND CULTURAL IMPORTANCE INDEX (CI) BETWEEN DAN SAGA AND TABOFATT CASES

\begin{tabular}{ccc} 
(CI) BETWEEN DAN SAGA AND TABOFATT CASES & \\
\hline Parameters & IVI & CI \\
\hline Difference & $-2,56$ & $-0,05$ \\
$\mathrm{t}$ (Observed value) & $-1,09$ & $-1,72$ \\
$|\mathrm{t}|$ (Critic value) & 1,99 & 1,99 \\
p-value & 0,28 & 0,09 \\
Threshold & 0,05 & 0,05 \\
Percentage of risk to reject $\mathrm{H} 0$ & $28,05 \%$ & $8,91 \%$ \\
\hline
\end{tabular}

The average of SVI is significantly higher with 5.77 . $1.65 \%$ in the Dan Saga cluster and $8.33 \cdot 0.68 \%$ in the case of Tabofatt cluster (Table 6).

TABLE 6: CORRELATION ANALySis RESUlt BETWEEN SigNifiCANCE VALUE INDEX (SVI) AND CULTURAL IMPORTANCE INDEX (CI) IN DAN

\begin{tabular}{ccccc}
\multicolumn{5}{c}{ SAGA AND TABOFATT CLUSTERS } \\
\hline Index & Dan Saga & Tabofatt \\
\hline & Mean value & $\mathrm{R}$ & Mean value & $\mathrm{R}$ \\
SVI & $5,77 \pm 1.65$ & 0.61 & $8,33 \pm 0.68$ & 0.60 \\
CI & $0,12 \pm 0.13$ & 0.61 & $0,17 \pm 0.15$ & 0.60 \\
\hline
\end{tabular}

Legend: R: Correlation ratio of Pearson.

But it is interesting to see through these results that the level of correlation between socioeconomic demand and ecological supply is clearly greater than 0.50 in both. It is 0.61 at the Dan Saga cluster level and 0.60 at the Tabofatt cluster level.

\section{DISCUSSION}

\section{A. Procurement Services}

This study showed that woody species tree occupy a preponderant place through food, forage, technological, energy and medicinal uses in the two clusters. This is expressed by the relatively high values of the Consensual Informative factor on the categories of uses. The rural populations of the restored landscapes are therefore unanimous on the importance of tree resources which they exploit for various purposes. In addition, the allocation of a species to a use depends on the location. Three groups of dual-use species were recorded at Tabofatt cluster and in contrast four of such groups at the Dan Saga cluster. However, the species-use relationships recorded by this study at the Dan Saga cluster are in accordance with those reported in the work of [4] in the same site. This reinforces the preponderant place of natural resources in rural areas. As an illustration, the [11] indicated that in Burkina Faso more than $80 \%$ of the population uses non-timber forest products. In Niger [27] evoked the important role of the Combretum micranthum species in the traditional pharmacopoeia in Tahoua region where the Tabofatt cluster is located. In the same region [3] identified 49 tree woody species available in rural markets that are endowed with medicinal properties. In the more humid south-eastern Niger, [9] identified 37 and 34 tree woody species used respectively for food and fodder purposes.

\section{B. Regulatory Services}

The regulation services offered by the woody component of restored landscapes can be seen from several angles. This role is ensured through soil stabilization by the roots, improvement of the organo-mineral and water status of soils. This study highlighted the importance of species belonging to the legume family recognized for their fertilizing role and are well represented in both landscapes. It shows a strong presence of these species expressed by their SVI value in both landscapes. In the Tabofatt cluster the importance of leguminous species is much higher compared to those of the Dan Saga cluster. This clear disparity in the vegetation facies between the two sites was confirmed with the results obtained by [27] and [13]. The two authors have studied the characterization of woody vegetation respectively in Dan Saga terroir and the Bagaroua zone (located in the same agroecological context as the Tabofatt cluster) in Niger. Even the species of other plant families such as the combretaceae, for example, contribute in strengthening the organic stock of the soils. In the Niger River terrace area, [16] reported that Balanites aegyptiaca improves significantly the organo-mineral status of soils under the crown compared to the part outside the crown.

In addition, this study has shown that the two landscapes restored through sustainable land management strongly contribute to the storage of atmospheric carbon. The sequestration potential is 6.04 and 4.59 tone of $\mathrm{CO}_{2} \cdot \mathrm{ha}^{-1}$ respectively at Dan Saga cluster and at Tabofatt. The widespread practice of ATNR, which significantly increases the density of tree woody in the landscape, explains the high potential for carbon sequestration. On the other hand, at Tabofatt cluster, the density of the woody cover depends on 
the actions of tree woody planting coupled with mechanical erosion control practices. At Dan Saga, 5.76 \pm 0.06 and $1.24 \pm 0.004$ tone of C.ha- ${ }^{-1}$ respectively were recorded for above-ground and below-ground biomass. Using the integral cut method, [29] had obtained on an agroforestry site in Burkina Faso a slightly lower quantity of carbon of $2.5 \pm 3.28$ and $0.35 \pm 0.42$ tone of C.ha ${ }^{-1}$ respectively on the aboveground biomass and the hypogeal biomass. According to the amount of $\mathrm{CO}_{2}$, the results of this study are close to those obtained by [10] who estimated the carbon stock of an agroforestry park in Senegal at 8.81 tone $\mathrm{CO}_{2} \mathrm{ha}^{-1}$.

Our study showed that the floral procession of two landscapes conceals a high diversity (5.5 bit in Dan Saga and 4.39 bit in Tabofatt). The specific richness of the terroirs is 47 species in Dan Saga and 21 species in Tabofatt. [27] had counted 37 species in Dan Saga landscape. This suggests that within two years the species richness has increased by ten new species. The sustained and widespread efforts of assisted tree natural regeneration (ATNR) practice may justify this marked improvement. The low specific richness of the Tabofatt cluster compared to that of Dan Saga could be related not only to the difference in land management practices used and probably to the difference in soil substrate and especially SLM practices types.

\section{Link between the Socioeconomic Importance of Species and Ecological Importance}

The statistical test applied to the CI and SVI parameters attests that there is no significant difference in the means between the two clusters. This means that part of the services provided by the agroforestry resources of these two landscapes is substantially similar. In addition, there is no great inter-cluster disparity in the importance of the species requested for these services. Social needs of tree resource services are quite related to the status of woody species in the landscape. In the same sense, [18] underline that the practice of ATNR promote a clear satisfaction in the need for wood for all types of use expressed by the population. [21] Indicated that the income generated by this practice is around 200,000 CFA francs (400 US\$) per household. According to [5] Agroforestry practices support the productive base of lands in arid and semi-arid zones.

\section{CONCLUSION}

The re-greening dynamics observed in certain areas of the Sahel required an update on the ecosystem services produced at the landscape. In keeping with this perspective, the objective assigned to this study was to assess the importance of supply and regulation services generated by agroforestry resources in such re-greened zones. The results showed that a diverse range of woody species are employed in meeting dietary, forage, technological, energetic and medicinal needs. There are much more marked use-species relationships at the Dan Saga cluster compared to the Tabofatt cluster. In both cases, the species requested for the various uses are relatively important in the landscape. Besides improving the soil, the biodiversity of tree woody species of these two landscapes contributes to the mitigation of climate change. These results suggest that it is important to orient regreening scaling approaches towards favoring multiple-use species. This is possible through the promotion of the widespread utilization of assisted tree natural regeneration practice, coupled with other forms of vegetative reproduction. This approach should be centered on the most useful tree species. It is therefore important to focus the regreening action on the basis of rural people needs of energy, traditional medicine, food and forage.

\section{ACKNOWLEDGMENT}

The authors are grateful to three students: ALLASSANE Ahmed, SALAMOU Mahamadou and MOUMOUNI Inoussa, who participate in data collection on the field.

\section{REFERENCES}

[1] Adam, T., et al. Impacts des investissements dans la gestion des ressources naturelles (GRN) au Niger: Rapport the synthèse. 2006.

[2] Arbonnier, M. Arbres, Arbustes et Lianes d'Afrique de l'Ouest (3ème édition). 2009.

[3] Baggnian, I., et al. «Etude ethnobotanique des plantes médicinales vendues sur les marchés du centre Ouest du Niger». J. Appl. Biosci., vol. 132, 2018, p. 13392-403.

[4] Baggnian, I. Résilience des agroécosystèmes au Sahel: analyse du reverdissement dans le centre Sud du Niger. PhD dissertation Abdou Moumouni de Niamey, 2014.

[5] Bationo, B. A., et al. Potentialités des ligneux dans la pratique de l'agriculture de conservation dans les zones arides et semi-arides de l'Afrique de l'Ouest : aperçu de quelques systèmes candidats. Nairobi 2012.

[6] Cairns, M. A., et al. «Root biomass allocation in the World's upland forests». Oecologia, vol. 111, 1997, p. 1-11.

[7] Carpenter, S. R., et al. «Millennium Ecosystem Assessment: Research Needs». Ecology-Science, vol. 314, 2007, p. 257-58.

[8] Costanza, R., et al. "Changes in the global value of ecosystem services». Global Environmental Change, vol. 26, 2014, p. 152-58.

[9] Dan Guimbo I. 2011. Fonction, dynamique et productivité des parcs à Vitellaria paradoxa C. F. Gaertn. et à Neocarya macrophylla (Sabine) Prance dans le Sud-Ouest du Niger. PhD dissertation, Université Abdou Moumouni de Niamey, 2011.

[10] Diatta, A. A., et al. «Services écosystémiques du parc agroforestier à Cordyla pinnata (Lepr. Ex A. Rich.) Milne-Redh., dans le Sud du bassin arachidier (Sénégal)». Int. J. Biol. Chem. Sci., vol. 10, $\mathrm{n}^{\circ} 6$, 2016, p. 2511-25.

[11] FAO. L'état des ressources en terres et en eau pour l'alimentation et L'agriculture dans le monde gérer les systèmes en danger. Rome Italie 2011.

[12] Feger, C., et al. «Grand cycle de l'eau, évaluation des services écosystémiques et aménagement du territoire: un grand retour d'expérience». Techniques-Sciences-Méthodes, vol. 110, nº 9, 2015, p. $56-67$.

[13] Garba, A., et al. «Caractérisation de la végétation ligneuse du bassin de la Maggia dans la commune rurale de Bagaroua (région de Tahoua)». Int. J. Biol. Chem. Sci., vol. 11, n 2, 2017, p. 571-84.

[14] Hama, O., et al. "Connaissances ethnobotaniques et usages de Combretum micranthum dans la pharmacopée traditionnelle au SudOuest de Tahoua (Niger, Afrique de l'Ouest)». Int. J. Biol. Chem. Sci., vol. 13, no 4, 2019, p. 2173-91.

[15] Heinrich, M., et al. «Medicinal plants in Mexico-healers consensus and cultural importance». Social Science and Medicine, vol. 47, $\mathrm{n}^{\circ} 11$, 1998, p. 1859-71.

[16] Idrissa, B., et al. «Effet de Balanites aegyptiaca sur le niveau de fertilité chimique d'un sol de terrasse du fleuve Niger». J. Appl. Biosci., vol. 137, 2019, p. 13940-50.

[17] IPCC. IPCC guidelines for national greenhouse gas inventories. Rapport technique, 4, 2006.

[18] Larwanou, M., A. M. Moustapha, et al. «Contribution de la Régénération Naturelle Assistée des Ligneux dans l'approvisionnement en bois des ménages dans le département de Magaria (Niger)». Int. J. Biol. Chem. Sci., vol. 6, n ${ }^{\circ}$ 1, 2012, p. 24-36.

[19] Larwanou, M., I. Oumarou, et al. «Pratiques sylvicoles et culturales dans les parcs agroforestiers suivant un gradient pluviométriques nord-sud dans la région de Maradi au Niger». Tropicultura, vol. $28, \mathrm{n}^{\circ}$ 2, 2010, p. 115-22. 
[20] Larwanou, M., et M. Saadou. «Biodiversity of ligneous species in semi-arid to arid zones of south-western Niger according to anthropogenic and natural factors». Agriculture, Ecosystems and Environment, vol. 105, 2005, p. 267-271.

[21] Lawali, S., et al. «Régénération Naturelle Assistée (RNA): outil d'adoption et de résilience des ménages ruraux d'Aguié au Niger». Int. J. Biol. Chem. Sci., vol. 12, no 1, 2018, p. 75-89.

[22] Malhi, Y., et al. «The above-ground coarse wood productivity of 104 neotropical forest plots». Global Change Biology, vol. 10, 2004, p. 563-91.

[23] Mazzucato, V., et D. Niemeijer. Le Sahel : une dégradation des terres exagérée, un potentiel paysan sous-estimé. Valentina, 2001.

[24] Mbow, C., et al. «Allometric models for above ground biomass in dry savanna trees of the Soudan and Soudan-Guinean ecosystems of southern Senegal». Journal of Forest Research, vol. 18, 2013, p. 340-47.

[25] Mcghee, W., et al. «Méthodes de calcul de la biomasse et du carbone des arbres en Afrique de l'Ouest». Annales des Sciences Agronomiques, vol. 20, n No Spécial, 2016, p. 79-98.

[26] Millennium Ecosystem Assessment. Ecosystems and Human wellbeing: Global Assessment Reports. Island Press Washington DC, 2005.

[27] Morou, B., et al. «Ressources forestières ligneuses: diversité et usages dans le terroir villageois de Dan Saga». Afrique Science, vol. $12, n^{\circ} 4,2016$, p. $228-39$.

[28] Mortimore, M., et B. Turner. «Does the Sahelian smallholder's management of woodland, farm trees, rangeland support the hypothesis of human-induced desertification?» Journal of Arid Environments, vol. 63, 2005, p. 567-595.

[29] Ouedraogo, W. O., et al. «Quantification de la biomasse et stockage du carbone du massif forestier de l'Ecole Nationale des Eaux et Forêts de Dindéresso, province de Houet au Burkina Faso». Int. J. Biol. Chem. Sci., vol. 13, $\mathrm{n}^{\circ}$ 7, 2019, p. 3276-88.

[30] Saidou, S., et J. M. K. Ambouta. «Part contributive de la densité démographique au reverdissement de certaines zones anthropisées du Sahel: cas des communes d'Aguié et Ibohamane». Int J. Biol. Chem. Sci., vol. $\quad 14, \quad \mathrm{n}^{\mathrm{o}} \quad 3, \quad 2020, \quad$ p. $816-34$ doi:https://doi.org/10.4314/ijbcs.v14i3.14.

[31] Seghieri, J. « Systèmes agroforestiers soudano-sahéliens. Tradition ou innovation?" Liaison Energie-Francophonie, Institut de la Francophonie pour le Développement Durable, 2017, p. 92-96.

[32] Tardio, J., et M. Pardo-de-Santayana. «Cultural importance indices: a comparative analysis based on the useful wild plants of southern Cantabria (Northern Spain)». Economic Botany, vol. 62, n 1, 2008, p. 24-39.

[33] Von Maydell, H. J. Arbres et arbustes du Sahel: leurs caractéristiques et leurs utilisations. Office Allemand de la Coopération Technique (GIZ), 1983.

[34] Zakari, A. H., et al. "Analyse de la faune entomologique associée à Jatropha curcas L. dans la région de Maradi au Sud-Est du Niger». Entomologie Faunistique, vol. 10, nº 66, 2013, p. 97-107.

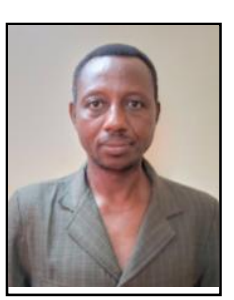

S. Saidou was born on 01.01.1978 in Niger Republic. $\mathrm{He}$ is currently a student in $\mathrm{PhD}$ Program at Doctorate School of Life and Earth Sciences at Abdou Moumouni University of Niamey. He is a holder of Master Degree in Environmental Protection and Improvement of Sahelian Agrarian Systems, of Regional Centre of Agricultural Studies, University of Niamey, Niger Republic.

$\mathrm{He}$ has more than ten years job experiences at the Ministry of Environment and Sustainable

Development of Niger Republic. These experiences include Program Manager of Urban Forestry Management and Non Timber Product Promotion at the National Agency of Sustainable Development.

He published two paper:

1. Saidou Salifou \& AMBOUTA Jean-Marie. Karimou. Part contributive de la densité démographique au reverdissement de certaines zones anthropisées du Sahel. International Journal of Biological and Chemical Sciences, vol 14 (3) 816-834, 2019.

2. Saidou Salifou \& Ambouta Jean-Marie. Karimou Recent landscapes dynamics in the anthropized Sahel zone's: from degradation to regreening, case study of Aguié and Ibohamane municipalities, Journal of Agriculture and Veterinary Sciences vol 13 (12), pp 2319-2380, 2020.

During his study career, he published one book titled: Agriculture front dynamic in the reserve zone of $\mathrm{W}$ park, UNESCO Man and Biospher Program.

Dr Saidou Salifou is a member of Students Fellowship Group of Niger. 